\title{
Minimally invasive approach to pneumothorax: Single port or two ports?
}

\author{
Pnömotoraksta minimal invaziv yaklaşım: Tek port mu, iki port mu?

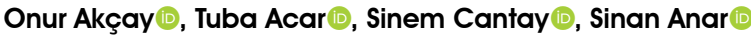 \\ Department of Thoracic Surgery, Çiğli Regional Training Hospital, Izmir, Turkey
}

\begin{abstract}
Background: This study aims to compare the effectiveness of single-port and two-port video-assisted thoracoscopic surgery in patients with pneumothorax.

Methods: Between June 2016 and December 2018, a total of 44 patients (39 males, 5 females; mean age 27.0 9.5 years; range, 15 to 60 years) who underwent video-assisted thoracoscopic surgery due to the spontaneous pneumothorax in our center were retrospectively evaluated. The study population was divided into two groups as the single-port $(n=29)$ and two-port $(n=15)$ procedure according to the number of port entries applied during the operation. Age, gender, number of days of drainage, length of hospitalization, number of days of air leak, the indication of operation, pneumothorax side, type of pneumothorax, duration of operation, and complications were compared between the groups.

Results: Twenty-two patients $(50 \%)$ were operated on the right side and 22 patients $(50 \%)$ on the left side. The mean operation time was $81.1 \pm 19.2 \mathrm{~min}$, indicating no significant difference between the groups $(p=0.053)$. No significant difference was observed in the number of days of drainage, the length of hospitalization, and number of days of air leak between the two groups. Complications developed in eight patients (27.6\%) in the single-port group and five patients $(33.3 \%)$ in the two-port group, indicating no significant difference between the groups $(\mathrm{p}=0.475)$.
\end{abstract}

Conclusion: Our study results show that video-assisted thoracoscopic surgery for the treatment of pneumothorax can be successfully performed via a single-port approach.

Keywords: Pneumothorax, single port, video-assisted thoracoscopic surgery.

Air collection in the pleural space without any trauma and concomitant pulmonary collapse are referred to as the spontaneous pneumothorax..$^{[1]}$ Video-assisted thoracoscopic surgery (VATS) is commonly performed
$\ddot{O} Z$

Amaç: $\mathrm{Bu}$ çalışmada pnömotoraks olan hastalarda tek port ve iki port video yardımlı torakoskopik cerrahinin etkinliği karşılaştırıldı.

Çalışma planı: Haziran 2016 - Aralık 2018 tarihleri arasında, spontan pnömotoraks nedeni ile hastanemizde video yardımlı torakoskopik cerrahi uygulanan toplam 44 hasta (39 erkek,

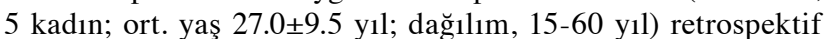
olarak değerlendirildi. Çalışma grubu operasyon sırasında uygulanan port giriş sayısına göre tek port $(n=29)$ ve iki port $(n=15)$ işlem olarak iki gruba ayrıldı. İki hasta grubu yaş, cinsiyet, drenaj gün sayısı, hastanede yatış süresi, hava kaçağı gün sayısı, ameliyat endikasyonu, pnömotoraks tarafı, pnömotoraks tipi, ameliyat süresi ve komplikasyonlar açısından karşılaştırıldı.

Bulgular: Yirmi iki hasta (\%50) sağ taraftan, 22 hasta (\%50) sol taraftan ameliyat edildi. Ameliyat süresi ortalama $81.1 \pm 19.2 \mathrm{dk}$. olup, gruplar arasında anlamlı bir fark gözlenmedi $(\mathrm{p}=0.053)$. İki grup arasında drenaj gün sayısı, hastanede yatış süresi ve hava kaçağı gün sayısı açısından anlamlı bir fark saptanmad1. Tek port grubunda sekiz hastada (\%27.6) ve iki port grubunda beş hastada (\%33.3) komplikasyon gelişti; gruplar arasında anlamlı bir fark bulunmadi $(\mathrm{p}=0.475)$.

Sonuç: Çalışma sonuçlarımız video yardımlı torakoskopik cerrahinin tek port yaklaşımı ile pnömotoraks tedavisinde başarılı bir şekilde yapılabileceğini göstermektedir.

Anahtar sözcükler: Pnömotoraks, tek port, video yardımlı torakoskopik cerrahi.

by thoracic surgeons. ${ }^{[2]}$ Compared to thoracotomy, VATS has certain advantages in terms of shorter hospital stay, less postoperative pain level, and more rapid time to return to normal life after surgery. ${ }^{[2,3]}$

Received:September 26, 2019 Accepted: December 16, 2019 Published online: April 22, 2020

Correspondence: Onur Akçay, MD. Çiğli Bölge Eğitim Hastanesi, Göğüs Cerrahisi Kliniği, 35620 Çiğli, İzmir, Türkiye.

Tel: +90 232 - 4333333 e-mail: onur_akcay@yahoo.com 
Pneumothorax is one of the indications for VATS. Surgical treatment of pneumothorax, which was previously carried out with thoracotomy, has been performed with VATS in recent years. ${ }^{[2]}$ Over the years, an uniportal approach has been developed as an alternative to the standard multi-port approach ${ }^{[4]}$ However, there is still a limited number of studies on uniportal VATS experience for the treatment of pneumothorax ${ }^{[5]}$ In this study, we aimed to compare the effectiveness of single-port (SP) and two-port (TP) VATS in patients with pneumothorax.

\section{PATIENTS AND METHODS}

In our center, VATS has been performed since June 2016 and the experience of both the service and operating room nurses, anesthesiologists, and operating room staffs is negligibly low. Between June 2016 and December 2018, a total of 44 patients (39 males, 5 females; mean age 27.0 \pm 9.5 years; range, 15 to 60 years) who underwent VATS due to the spontaneous pneumothorax in our center were retrospectively evaluated. Patients who underwent thoracotomy or a video-thoracoscopic operation and converted to thoracotomy were excluded from the study. The study population was divided into two groups as the SP-VATS $(n=29)$ and TP-VATS $(n=15)$ according to the number of port entries applied during the operation. The patient files were screened and age, gender, number of days of drainage, length of hospitalization, number of days of air leak, the indication of operation, pneumothorax side, type of pneumothorax, duration of operation, and complications were compared between the groups. A written informed consent was obtained from each patient. The study protocol was approved by the Çiğli Regional Training Hospital Ethics Committee. The study was conducted in accordance with the principles of the Declaration of Helsinki.

\section{Surgical technique}

Routine blood tests, chest radiography, and thoracic computed tomography were performed to each patient. All patients underwent double-lumen intubation under general anesthesia. The operation was performed in the lateral decubitus position. Using the SP-VATS approach, the former or existing tube thoracostomy incision was used, or a new incision of about $2 \mathrm{~cm}$ was made at the intersection of the seventh intercostal space and the mid-axillary line. In the TP-VATS, the former or existing tube thoracostomy incision was used for the inferior port entry, while the intersection at the third intercostal space and the mid-axillary line was used for the superior port entry.
A 30-degree-angled optic was placed using the 11-mm thoracic port following deflating of the lung. Endoforceps were used to grasp the bullae and $60-\mathrm{mm}$ endostaplers were used for resection of the bullous region. The apical pleurectomy was, then, performed. Following hemostasis and air leak control, the operation was terminated by inserting a 32-Fr chest tube into the thorax from the existing port entry to the patients who underwent SP-VATS and from the inferior port entry to the patients who underwent TP-VATS. All patients were extubated in the operating room.

\section{Statistical analysis}

Statistical analysis was performed using the IBM SPSS version 22.0 software (IBM Corp., Armonk, NY, USA). Descriptive data were expressed in mean \pm standard deviation (SD), median (min-max) or number and frequency. The Student's t-test and one-way analysis of variance (ANOVA) were used to compare mean values. Categorical variables were analyzed using the Fisher's exact test or Pearson chi-square test. A $p$ value of $<0.05$ was considered statistically significant with $95 \%$ confidence interval (CI).

\section{RESULTS}

Twenty-two patients $(50 \%)$ were operated on the right side and 22 patients $(50 \%)$ on the left side. Gender distribution did not differ significantly between the groups $(p=0.209)$. However, there was a statistically significant difference in the mean age between the groups $(25.4 \pm 7.2$ years vs. $29.9 \pm 12.7$ years in the SP-VATS and TP-VATS group, respectively) $(\mathrm{p}=0.028)$. Of the patients, $41(93.2 \%)$ were operated for primary spontaneous pneumothorax and three (6.8\%) for secondary spontaneous pneumothorax. No significant difference was observed between the two groups $(p=0.264)$. The etiology of secondary spontaneous pneumothorax was bullous emphysema in one patient and tuberculosis in two patients (Table 1).

The indications for operation were prolonged air leak (PAL) and recurrent pneumothorax. In the SP-VATS group, 20 patients $(69 \%)$ underwent surgery due to recurrent pneumothorax and nine patients (31\%) due to PAL. In the TP-VATS group, 13 patients $(86.7 \%)$ were operated due to recurrent pneumothorax and two patients $(13.3 \%)$ due to the PAL. No significant difference was found between the two groups in terms of operation indications ( $\mathrm{p}=0.181)$ (Table 2).

The mean duration of operation was $81.1 \pm 19.2 \mathrm{~min}$ $(78.6 \pm 16.0 \mathrm{~min}$ vs. $86 \pm 24.1 \mathrm{~min}$ in the SP-VATS and TP-VATS group, respectively), indicating no significant difference $(p=0.053)$. In addition, there 
Table 1. Demographic and clinical characteristics of patients

\begin{tabular}{|c|c|c|c|c|c|c|c|c|c|c|}
\hline & \multicolumn{3}{|c|}{ SP-VATS $(n=29)$} & \multicolumn{3}{|c|}{ TP-VATS $(n=15)$} & \multicolumn{3}{|c|}{ All Groups $(n=44)$} & \multirow[b]{2}{*}{$p$} \\
\hline & $\mathrm{n}$ & $\%$ & Mean \pm SD & $\mathrm{n}$ & $\%$ & Mean \pm SD & $\mathrm{n}$ & $\%$ & Mean \pm SD & \\
\hline Age (year) & & & $25.4 \pm 7.2$ & & & $29.9 \pm 12.7$ & & & $27.0 \pm 9.5$ & 0.028 \\
\hline Gender & & & & & & & & & & 0.209 \\
\hline Female & 2 & 6.9 & & 3 & 20 & & 5 & 11.4 & & \\
\hline Male & 27 & 93.1 & & 12 & 80 & & 39 & 88.6 & & \\
\hline Type & & & & & & & & & & 0.264 \\
\hline Primary & 28 & 96.6 & & 13 & 86.7 & & 41 & 93.2 & & \\
\hline Secondary & 1 & 3.4 & & 2 & 13.3 & & 3 & 6.8 & & \\
\hline Side & & & & & & & & & & 0.500 \\
\hline Right & 14 & 48.3 & & 8 & 53.3 & & 22 & 50 & & \\
\hline Left & 15 & 51.7 & & 7 & 46.7 & & 22 & 50 & & \\
\hline
\end{tabular}

SP-VATS: Single-port video-assisted thoracoscopic surgery; TP-VATS: Two-port video-assisted thoracoscopic surgery; SD: Standard deviation.

Table 2. Postoperative data

\begin{tabular}{|c|c|c|c|c|c|c|c|c|c|c|}
\hline & \multicolumn{3}{|c|}{ SP-VATS $(n=29)$} & \multicolumn{3}{|c|}{ TP-VATS $(n=15)$} & \multicolumn{3}{|c|}{ All Groups $(n=44)$} & \multirow[b]{2}{*}{$p$} \\
\hline & $\mathrm{n}$ & $\%$ & Mean \pm SD & $\mathrm{n}$ & $\%$ & Mean \pm SD & $\mathrm{n}$ & $\%$ & Mean \pm SD & \\
\hline Cause & & & & & & & & & & 0.181 \\
\hline PAL & 9 & 31 & & 2 & 13.3 & & 33 & 75 & & \\
\hline Recurrence & 20 & 69 & & 13 & 86.7 & & 11 & 25 & & \\
\hline Duration of operation (min) & & & $78.6 \pm 16.0$ & & & $86 \pm 24.1$ & & & $81.1 \pm 19.2$ & 0.053 \\
\hline Air leak (days) & & & $3.4+2.4$ & & & $3.2+2.1$ & & & $3.3+2.3$ & 0.420 \\
\hline Drainage (days) & & & $7.1+4.4$ & & & $8.3+4.4$ & & & $7.5+4.4$ & 0.511 \\
\hline Hospitalization (days) & & & $7.0+2.4$ & & & $6.5+1.1$ & & & $6.9+2.1$ & 0.142 \\
\hline Complication & & & & & & & & & & 0.475 \\
\hline No & 21 & 72.4 & & 10 & 66.7 & & 31 & 70.5 & & \\
\hline Yes & 8 & 27.6 & & 5 & 33.3 & & 13 & 29.5 & & \\
\hline
\end{tabular}

SP-VATS: Single-port video-assisted thoracoscopic surgery; TP-VATS: Two-port video-assisted thoracoscopic surgery; SD: Standard deviation; PAL: prolonged air leak.

was no significant difference in the number of drainage days, length of hospitalization, and number of days with air leak between the two groups (Table 2). Complications developed in eight patients $(27.6 \%)$ in the SP-VATS group and five patients $(33.3 \%)$ in the TP-VATS group. These complications were PAL in six patients, insufficient expansion of the lung in six patients, and re-expansion pulmonary edema in one patient. Eleven of the patients who developed insufficient expansion and PAL were discharged with a one-way valve system, and their drain was terminated during the outpatient clinic follow-up. No significant difference was found between the two groups in terms of complications $(p=0.475)$ (Table 2). In a patient in the SP-VATS group, recurrence was observed and this patient was re-operated three months after the first operation.

\section{DISCUSSION}

At the beginning of the 1990s, blebectomy and bullectomy via VATS for spontaneous pneumothorax became available in many centers with the developments in thoracoscopic instruments and techniques. ${ }^{[6]}$ Compared to open surgery, it has been clearly shown that traditional VATS has a greater advantage in terms of shorter postoperative stay, operative time, and duration of chest tube drainage and less postoperative pain, and more rapid recovery due to its less invasive nature. ${ }^{[7-9]}$

Video-assisted thoracoscopic surgery using a SP is a safe and effective approach for the surgical treatment of pneumothorax. ${ }^{[5]}$ An acceptable rate of recurrence, better patient satisfaction, and improved tolerability are shown in the VATS technique. ${ }^{[4]}$ In this 
method, conventional two- or three-port approaches are preferred. The SP approach has emerged as an alternative to the traditional method. ${ }^{[6,7]}$ The SP-VATS technique was first described by Migliore and popularized by Rocco et al. ${ }^{[10-13]}$ In 2013, they published their 10-year experience. ${ }^{[14]}$ The singleincision technique has gained popularity over the past few years, compared to multiple incisions. ${ }^{[2]}$

In their study, Yang et al. ${ }^{[15]}$ reported that both the operation time and the length of hospital stay decreased significantly in the SP group. They also showed that the SP group had significantly less pain on the same day, the first day, and the second day of the operation. Nachira et al. ${ }^{[7]}$ showed no significant difference between the SP and three-port VATS groups in terms of mortality, recurrence, and complications and reported that SP-VATS technique was clinically as safe as three-port VATS technique. The results of a recent meta-analysis also support these findings. ${ }^{[16]}$ Ocakcioglu et al. ${ }^{[6]}$ found that the operation time was slightly shorter, although there was no significant difference between the SP and two- and three-port procedures. In the aforementioned study, they reported that there was no recurrence in the SP-VATS group. Song et al. $^{[17]}$ also reported that the duration of hospitalization was shortened; however, there were more complications in the SP-VATS group. ${ }^{[17]}$ Another recent meta-analysis revealed that the uniportal VATS approach did not prolong the duration of postoperative drainage and hospital stay. ${ }^{[18]}$

On the other hand, Kim et al. ${ }^{[19]}$ reported some difficulties in the surgical technique of the SP-VATS, compared to three-port approach, with prolonged operation time with the SP-VATS. Blood leakage from the subcutaneous or muscle structures at the port entrance may adversely affect the image quality, thus extending the operating time. ${ }^{[6]}$ In the study of Kutluk et al., ${ }^{[2]}$ the operation time of the approach with two ports was shorter than the SP, although there was no significant difference. Even though the operation time was shorter with the SP approach in our study, there was no significant difference between the groups $(p=0.053)$.

The key to success in the uniportal approach is the use of an angled $\left(30^{\circ}\right)$ thoracoscope and staplers with articulation. ${ }^{[4,11,13]}$ Also, the intercostal space is required to be dissected widely so that the extensive mobility of all instruments can be ensured. Therefore, the size of the intercostal opening should be much larger than the skin incision. ${ }^{[5]}$

In pneumothorax surgery, bullectomy and pleurodesis are the most effective treatments which reduce the recurrence rate. ${ }^{[7]}$ According to the British
Thoracic Society report, bullectomy and pleurodesis are recommended for the surgical treatment of recurrence. ${ }^{[20]}$ Although many thoracic surgeons prefer mechanical pleural abrasion or pleurectomy for benign diseases, there is no study comparing the significant long-term complications of talc pleurodesis in young patients. ${ }^{[5]}$ In our routine practice, we also prefer the apical pleurectomy method for pleurodesis in our patients.

The main limitation of this study is the lack of sufficient experience of anesthesiologists, nurses, and other personnel in thoracic surgery in our center.

In conclusion, with the advancing technology, the number of minimally invasive approaches in thoracic surgery has been increasing. Minimally invasive lung resections can be successfully performed using a single incision. Based on our study results, single-port videoassisted thoracoscopic surgery is a safe and effective method for the treatment of pneumothorax.

\section{Acknowledgment}

The authors thank Özgür Samancılar, MD for his valuable support.

\section{Declaration of conflicting interests}

The authors declared no conflicts of interest with respect to the authorship and/or publication of this article.

\section{Funding}

The authors received no financial support for the research and/or authorship of this article.

\section{REFERENCES}

1. Yazkan R, Han S. Pathophysiology, clinical evaluation and treatment options of spontaneous pneumothorax. Tuberk Toraks 2010;58:334-43.

2. Kutluk AC, Kocaturk CI, Akin H, Erdogan S, Bilen S, Karapinar K, et al. Which is the Best Minimal Invasive Approach for the Treatment of Spontaneous Pneumothorax? Uniport, Two, or Three Ports: A Prospective Randomized Trail. Thorac Cardiovasc Surg 2018;66:589-94.

3. Salati M, Brunelli A, Xiumè F, Refai M, Sciarra V, Soccetti A, et al. Uniportal video-assisted thoracic surgery for primary spontaneous pneumothorax: clinical and economic analysis in comparison to the traditional approach. Interact Cardiovasc Thorac Surg 2008;7:63-6.

4. Bertolaccini L, Pardolesi A, Brandolini J, Solli P. Uniportal video-assisted thoracic surgery for pneumothorax and blebs/ bullae. J Vis Surg 2017;3:107.

5. Masmoudi H, Etienne H, Sylvestre R, Evrard D, Ouede R, Le Roux M, et al. Three Hundred Fifty-One Patients With Pneumothorax Undergoing Uniportal (Single Port) VideoAssisted Thoracic Surgery. Ann Thorac Surg 2017;104:254-60.

6. Ocakcioglu I, Alpay L, Demir M, Kiral H, Akyil M, Dogruyol T, et al. Is single port enough in minimally surgery for pneumothorax? Surg Endosc 2016;30:59-64. 
7. Nachira D, Ismail M, Meacci E, Zanfrini E, Iaffaldano A, Swierzy M, et al. Uniportal vs. triportal video-assisted thoracic surgery in the treatment of primary pneumothorax-a propensity matched bicentric study. J Thorac Dis 2018;10:S3712-S9.

8. Sawada S, Watanabe Y, Moriyama S. Video-assisted thoracoscopic surgery for primary spontaneous pneumothorax: evaluation of indications and long-term outcome compared with conservative treatment and open thoracotomy. Chest 2005;127:2226-30.

9. Goto T, Kadota Y, Mori T, Yamashita S, Horio H, Nagayasu $\mathrm{T}$, et al. Video-assisted thoracic surgery for pneumothorax: republication of a systematic review and a proposal by the guideline committee of the Japanese association for chest surgery 2014. Gen Thorac Cardiovasc Surg 2015;63:8-13.

10. Jutley RS, Khalil MW, Rocco G. Uniportal vs standard three-port VATS technique for spontaneous pneumothorax: comparison of post-operative pain and residual paraesthesia. Eur J Cardiothorac Surg 2005;28:43-6.

11. Migliore M, Deodato G. A single-trocar technique for minimally-invasive surgery of the chest. Surg Endosc 2001;15:899-901.

12. Rocco G, Martin-Ucar A, Passera E. Uniportal VATS wedge pulmonary resections. Ann Thorac Surg 2004;77:726-8.

13. Migliore M. Efficacy and safety of single-trocar technique for minimally invasive surgery of the chest in the treatment of noncomplex pleural disease. J Thorac Cardiovasc Surg 2003;126:1618-23.

14. Rocco G, Martucci N, La Manna C, Jones DR,
De Luca G, La Rocca A, et al. Ten-year experience on 644 patients undergoing single-port (uniportal) videoassisted thoracoscopic surgery. Ann Thorac Surg 2013;96:434-8.

15. Yang HC, Cho S, Jheon S. Single-incision thoracoscopic surgery for primary spontaneous pneumothorax using the SILS port compared with conventional three-port surgery. Surg Endosc 2013;27:139-45.

16. Yang Y, Dong J, Huang Y. Single-incision versus conventional three-port video-assisted surgery in the treatment of pneumothorax: a systematic review and meta-analysis. Interact Cardiovasc Thorac Surg 2016;23:722-8.

17. Song IH, Lee SY, Lee SJ. Can single-incision thoracoscopic surgery using a wound protector be used as a first-line approach for the surgical treatment of primary spontaneous pneumothorax? A comparison with three-port videoassisted thoracoscopic surgery. Gen Thorac Cardiovasc Surg 2015;63:284-9.

18. Qin SL, Huang JB, Yang YL, Xian L. Uniportal versus three-port video-assisted thoracoscopic surgery for spontaneous pneumothorax: a meta-analysis. J Thorac Dis 2015;7:2274-87.

19. Kim MS, Yang HC, Bae MK, Cho S, Kim K, Jheon S. Single-port video-assisted thoracic surgery for secondary spontaneous pneumothorax: preliminary results. Korean $\mathbf{J}$ Thorac Cardiovasc Surg 2015;48:387-92.

20. MacDuff A, Arnold A, Harvey J; BTS Pleural Disease Guideline Group. Management of spontaneous pneumothorax: British Thoracic Society Pleural Disease Guideline 2010. Thorax 2010;65:ii18-31. 